\title{
Prediction of Gestation in Women with Subchorial Hematoma
}

\author{
Kramarsky VA* \\ Irkutsk State Medical Academy of Postgraduate Education-affiliate RMANPO, Irkutsk State Medical University, Russia
}

Submission: August 13, 2020; Published: August 17, 2020

*Corresponding author: Kramarsky VA, Irkutsk State Medical Academy of Postgraduate Education-affiliate RMANPO, Irkutsk State Medical University, Russia

\section{Abstarct}

The birth of a baby is indeed the most wonderful event in most people's lives, but sometimes childbirth simply does not go as imagined in the family. Most women want to give birth naturally, and few are ready for an caesarean section. Caesarean section is indicated when childbirth is naturally harmful to the mother or for the fetus or for both. It is also indicated in the presence of contraindications for vaginal birth, when such conditions occur in pregnancy or during childbirth that the pregnancy must be to finish urgently, and vaginal delivery is not possible or unsuitable. An emergency caesarean section is sometimes needed to prevent the health complications for the mother or for baby or to save the life of the mother and baby. What can an doctor in Emergency department do when he or she gets a pregnant patient with a particular health problem or problems? He or she must contact the gynecologist, a specialist in obstetrics, as soon as possible which decide what to do. The doctor in ED will thus provide the medical service to the pregnant patient in the best possible way. Both the doctor in ED and the gynecologist obstetrician will undertake such procedures in accordance with the rules of the profession. If they did otherwise, their actions would have enormous health and legal consequences.

Keywords: Baby; Mother; Emergency; Cesarean Delivery

\section{Mini Review}

Prediction of gestation in women with a terminated pregnancy and the presence of subchorial hematoma is one of the promising directions for the optimal realization of reproductive potential. The aim of the work was to determine the significance of the dynamics of the size of the subchorial hematoma and the qualitative features of blood flow in this area for predicting gestation [1].

A study was conducted of 90 pregnant women with clinical manifestations of the begun abortion in the period from 10 to 16 weeks of pregnancy and the presence of subchorial hematoma. All pregnant women received gestagens dihydrosterone $20-40 \mathrm{mg}$ per os daily (54 people) or micronized progesterone $400-600 \mathrm{mg}$ vaginally (36 people). Upon admission to the hospital and upon discharge from the hospital, hematoma sizes (conditional area) were determined and blood flow was estimated in the area of the hematoma projection or the zone of its previous location. Doppler blood flow assessment was carried out according to three qualitative features diffuse blood flow - restored, lacunar (lake) partially restored and blocked - lack of blood flow. The presence of systole and diastole was regarded as physiological blood flow.
Definition of only diastole was characterized as partial restoration and inferiority of blood flow [2].

After the initiation of treatment, clinical improvement (disappearance of a lower abdomen) occurred in all women on the first day, and the disappearance of the clinical manifestations of abortion (spotting from the vagina) by 3-4 days. Decrease in the hematoma conditional area after completion of treatment in $40(44.4 \%)$ people, complete resorption of the hematoma in $10(11.1 \%)$ women, in $38(42.2 \%)$ hematoma sizes remained unchanged, and in $2(2.2 \%)$ it even increased slightly. The hematoma area on average decreased by $38.7 \pm 1.1 \%$. According to Dopplerometry, restoration of blood flow occurred in 57 (63.3\%) women, partial recovery in $28(31.1 \%)$ and blocked blood flow remained in 5 (5.6\%) pregnant women, but who did not have a clinic for the threat of termination of pregnancy [3].

Until the end of pregnancy, only 76 pregnant women were tracked. Of which 58 (76.3\%) were reported before the gestational age, while asymmetric mild IUGR was detected only in $4(7.1 \%)$ newborns. Premature pregnancy at 32-36 weeks was 
observed in $18(23.7 \%)$ with signs of IUGR (44.4\%) of newborns Among women with the full-term pregnancy in all observations reduction or a full rassasyvaniye of subchorial hematomas was noted. At the same time complete recovery of a blood-groove was at $49(84.5 \%)$ the person, and partial at $9(15.5 \%)$. In group of women with prematurely born pregnancy at $12(66.7 \%)$ the lack of a rassasyvaniye of a hematoma and only at $6(33.3 \%)$ its partial reduction is noted. In one of these observations the subchorial blood stream completely was not restored. Thus, reduction of subchorial hematomas or their full rassasyvaniye with the partial or completely restored blood-groove, as a result of the carried-out treatment, is optimum predictive sign on pregnancy incubation.

\section{References}

1. Tchaikovsky K, Syenko YA, Mogilinsky M, Vros M, Shchepitsa R, et al. (2007) A Chaykovskaya Uterine плаценьтарный a blood stream in early durations of gestation at the menacing abortion against the background of use of the vaginal micronized progesterone or an oral did rogesteron. Fertility and Sterility 87(3).

2. Spitz IM (2003) Progesterone antagonists and progesterone receptor modulators, an overview. Steroids 68(10-13): 981-983.

3. Makikalio K, Tekay A, Jouppila P (2004) Uteroplacental hemodinamics during early human pregnancy longitudinal study. Gynecol Obstet Invest 58(1): 49-54.

\section{Your next submission with Juniper Publishers will reach you the below assets}

- Quality Editorial service

- Swift Peer Review

- Reprints availability

- E-prints Service

- Manuscript Podcast for convenient understanding

- Global attainment for your research

- Manuscript accessibility in different formats

( Pdf, E-pub, Full Tsext, Audio)

- Unceasing customer service

Track the below URL for one-step submission https://juniperpublishers.com/online-submission.php 